\title{
Plant Extracts in Post-Harvest Disease Management of Fruits and Vegetables-A Review
}

\author{
Anjum Malik A ${ }^{1}$, Naseer Ahmed ${ }^{2 *}$, Babita $^{3}$, Harmeet Chauhan ${ }^{1}$ and Prerna Gupta ${ }^{1}$ \\ ${ }^{1}$ Division of Post-Harvest Technology, Sher-e-Kashmir university of Agricultural Science and Technology, Jammu, India \\ ${ }^{2}$ Choudhary Charan Singh Hisar Agriculture University, Hissar, Haryana, India \\ ${ }^{3}$ Department of Fruit Science, Dr. Y S Parmar University of Horticulture and Forestry, Nauni-Solan, HP, India
}

\begin{abstract}
Purpose of research: This review focus of the utilization of plant extracts in the post harvest management of fruits and vegetables and this also emphasize the need for future research.

Findings: Plant products are an important source of agrochemicals used for the control various post harvest loses which include diseases as well as insect pests. The widely studied plants in this context are the neem tree (Azadirachta indica), chinaberry (Melia azadrach) and marigold (Tagetes spp). They are being used to manufacture natural or bio insecticides, which are environmental friendly and do not have any toxic effects on plants and soil. More ever they possess fungicidal and insecticidal properties. Various extracts such as neem leaf extract, castor oil and neem oil on citrus fruits and reported that, among these extracts neem was best in retaining most of biochemical characteristics such as TSS $\left(16.01^{\circ} \mathrm{B}\right)$, acidity $(0.38 \%)$, pectin $(0.98 \%)$ and ascorbic acid content $(20.56 \mathrm{mg} / 100 \mathrm{ml}$ juice $)$.
\end{abstract}

Directions for future research: Each of these categories requires further research. The industries would benefit from this article on the utilization of plant extract post harvest management of fruits and vegetables. There are several areas which require further exploration. One of these is the development of technologies for the extraction of plant extract and its awareness about the safety of its utilization without any effect on human health.

Keywords: Neem; Chinaberry; Marigold; Post harvest management

\section{Introduction}

Although satisfactory control of the disease by using various chemicals have been documented in the literature [1-3] during recent years, global concern for protection of the environment has led researchers to investigate the use of natural flora as one of the sources for crop protection [4]

Antimicrobial activity of water and ethanolic extracts from five medicinal plants against bacteria isolated from disease fairy shrimps. The antimicrobial efficacy of Andrographis paniculata, Garcinia mangostana, Psidium guajava, Punica granatum and Terninalia catappa was evaluated against four gram negative bacteria including Aeromonas sobria, Klebsiella pneumonia, Enterobacter sp. and Chryseobacterium $s p$. using agar well diffusion method at three concentration levels (100, 10 and $1 \mathrm{mg} / \mathrm{ml}$ ). Among the tested plants, Punica granatum extract showed the highest level of antimicrobial activity against all four bacterial strains at $10 \mathrm{mg} / \mathrm{ml}$. The ethanolic extract of Punica granatum was very active against Aeromonas sobria at a concentration of 3.125 $\mathrm{mg} / \mathrm{ml}$.

A considerable amount of work has been carried out all over the world on the effect of plant extracts on the quality and shelf life in various fruit and vegetable crops. Fungal infections are one of the major causes of post harvest rots of fresh fruits and vegetables whether in transit or storage. They cause significant economic losses in the commercialization phase,and are rendered unfit for human consumption. Neem (Azadirachta indica A. Juss) and chinaberry (Melia azadrach) are two trees belonging to the mahogany family (Meliaceae). Neem is an evergreen tree [5], whereas chinaberry is a deciduous tree native to South Asia Australia. Fishwick [6] and Eeswara [7] studied the reputed value for its antifungal properties. Siddiqui et al. [8] evaluated the efficacy of leaf extract of neem (Azadirachta indica) and Chinaberry (Melia azadrach) against two tomato pathogenic fungi Alternaria solani and Fusarium oxysporium, the causal agents of early blight and wilt disease of tomato plants respectively were studied. Leaf extracts of different concentration (5\%,10\%,15\% and $20 \%)$ of aqueous, ethanol and ethyl acetate of neem and chinaberry were added to growth media prior to inoculation. Inhibition values recorded characteristic variation between neem and chinaberry. In case of neem inhibition percentages were $17.88 \%, 23.66 \%, 52.77 \%$ and $70.50 \%$ against Alternaria solani. While for F. oxysporum were $14.77 \%, 23.88 \%, 31.22 \%$ and $100 \%$ for all four concentrations used. Whereas for chinaberry inhibition values for Alt. solani is $3.11 \%, 5.22 \%, 5.53 \%$, and $5.77 \%$ and $5.44 \%, 6.11 \%, 6.35 \%$ and $6.55 \%$ for F. oxysporum [9]. The efficacy of the two plant extracts against the tomato fruit rot fungi was tested in vitro. The results showed that, the extracts significantly $(\mathrm{P}<0.05)$ inhibited the mycelial growth of the fungal pathogens at the different concentrations tested and the rate of inhibition differed from one extract to the other. Ilondu et al. [10] reported that some plants contain phenolic substances and essential oils, which are inhibitory to micro-organisms. The presence of these compounds in these extracts has been reported to be responsible for their antifungal properties [11]. These antifungal properties control various pests including fungi while the extract of ginger rhizomes is specially valued for their effectiveness against fungi [11].

\section{Literature Review}

Azadirachtin is considered as the most active principal substance in neem which has growth regulating, fungicidal and insecticidal

${ }^{*}$ Corresponding author: Naseer Ahmed, Choudhary Charan Singh Hisar Agriculture University Hissar, Haryana-125004, Tel: 9086024386; E-mail: ewsjammu@gmail.com

Received April 18, 2016; Accepted May 06, 2016; Published May 13, 2016

Citation: Anjum Malik A, Ahmed N, Babita, Chauhan H, Gupta P (2016) Plant Extracts in Post-Harvest Disease Management of Fruits and Vegetables-A Review. J Food Process Technol 7: 592. doi:10.4172/2157-7110.1000592

Copyright: ( 2016 Anjum Malik A, et al. This is an open-access article distributed under the terms of the Creative Commons Attribution License, which permits unrestricted use, distribution, and reproduction in any medium, provided the original author and source are credited. 
properties. Biopesticides are a good alternative to the synthetic pesticide. Both leaves and fruit of neem plant are known to have bitter taste having fungicidal, insecticidal and nematicidal properties. Azadirachtin, chemically a tetranorterpenoid component of neem acts on the mitotic cells and blocks the microtubule polymerization. Certain activities of genes and proteins are also altered by azadirachtin. As a botanical insecticide azadirachtin is effective against many biological processes. It may cause a reduction in feeding habit, suspend the molting process, larvae and pupae death and also cause sterility in the emerging adults, this all depend on the given dose. Apart from azadirachtin, many other components of neem also have insecticidal properties. Among them are saponins that are found to have antimicrobial activity that inhibits moulds and protecting plant from attack of insects [12]. Many biologically active compounds have been isolatedfrom neem, Azadirachta indica A. Juss, including triterpenoids, azadirachtin [13] and melantriol [14]. This reduced the feeding of insects. Azadirachtin is a mixture of seven isomeric compounds as Azadirachtin-A to Azadirachtin-G of which Azadirachtin-E is the most effective insect growth regulator [15]. Azadirachtin possess insecticidal, ovicidal, antifeedant and growth inhibiting effects against many insect pests [16-18]. Azadirachtin has minimal impact on nontarget organisms and is compatible with other eco-friendly bio control agents [19]. Effects of a botanical pesticide, azadirachtin, were evaluated on non-target aquatic macroinvertebrates found in SW Montana. A neem product formulated for commercial use and its petroleum-based, inert carrier alone were used to test the hypothesis that a commercial, U.S. Environmental Protection Agency-approved formulation of the pesticide, azadirachtin-A, derived from extracts of neem tree seeds, Azadirachta indica A. Juss. (Family: Meliaceae), is toxic to nontarget aquatic macroinvertebrates in Montana river systems. LC50 s (24 h) for 5 insect species, Drunella grandis (McDunnough), Drunella doddsi (Needham), Skwala parallela (Frison), Brachycentrus occidentalis Banks, and Brachycentrus americanus (Banks), and 1 isopod species, Caecidotea inter-media (Forbes) varied from $1.8 \mathrm{ppm}$ to $9.2 \mathrm{ppm}$ of the full formulation. The full formulation consisted of: azadirachtin $(3 \%$ wt:wt); other neem-extracted material ( $32 \% \mathrm{wt} / \mathrm{wt})$; petroleum solvents (65\% wt:wt). LT50 s for $4 \mathrm{ppm}$ of this formulation was 9.4 to 748 hours for these peld-collected macro- invertebrates. Without azadirachtin, but with the petroleum-based carrier, LT50 s was $13.6 \mathrm{~h}$ to $46.7 \mathrm{~h}$. These bioassays conducted late in winter and early spring of 1994 and 1995 and late summer and early fall of 1994 indicated mortality from the neem formulation was similar to herbicides 2,4-D and picloram, but mortality could be accounted for by action of petroleum solvents in the inert materials. This suggests the registration process of new pesticides should also include documented potential toxicity of inert components in the formulation to non-target aquatic insects [20]. Marigold belongs to the genus Tagetes (Asteraceae) with 56 species and includes the popular ornamental budding plants known as marigolds. Deshmukh et al. [21] have reported the beneficial effect of Tagetes erecta flower on various horticultural and agricultural crops, which are attributed primarily to the presence of an organic compound 'camacin' exhibiting antifungal and insecticidal effect. Chauhan et al. [22] treated apple cv. Starking delicious with plant leaves/flower based formulation of neem leaf extract $(10 \%, 20 \%)$, spearmint (Mentha spicata) leaf extract (10\%, $20 \%)$, marigold (Tagetes erecta) flower extract (10\%, 20\%) and semper fresh (control 1.5\%). Freshly harvested fruits were treated with above treatments and were kept under refrigerated storage $\left(1 \pm 1^{\circ} \mathrm{C}\right)$ for analysis at a month interval up to 180 days. Among treatments, $20 \%$ spearmint leaf extract proved to be highly effective in reducing fruit spoilage followed by $20 \%$ neem leaf extract. Fruit treated with $20 \%$ drake leaf extract proved to be most effective treatment in reducing weight loss and also $20 \%$ drake and $20 \%$ neem leaf extract were capable to retain maximum total soluble solids.

Pandey et al. [23] applied leaf extracts of Mentha and Melia to guava fruits and observed that these treatments were effective in retaining physical quality characteristics of fruits as they reduced moisture loss and storage rot symptoms. Rameshwar et al. [24] also observed that a combination of neem leaf extract at $20 \%+$ UV radiation exposure for 10 minutes + rice starch $6 \%$ proved to be the most appropriate treatment in minimizing the reduction of juice contents and fruit rotting and fluctuation in physiological loss in weight was also minimum as compared to control.

Hasabnis and D' souza [25] reported beneficial effects of natural plant products for the control of storage rots in Alphonso mango. They further reported that these treatments also checked the incidence of disease development in banana. Neem is the most promising and widely used against a number of insect pests due to its versatile mode of action. It has a broad spectrum action on insects and is very useful. However, the problems of quality, shelf life, presence of aflatoxins and phytotoxicity limit its efficacy and eco-safet. Rameshwar et al. [26] observed that a combination of neem leaf extract at $20 \%+$ UV radiation exposure for 10 minutes + rice starch $6 \%$ proved to be the most appropriate treatment in minimizing the reduction of juice contents and fruit rotting and fluctuation in physiological loss in weight was also minimum as compared to control. Wijewardane and Guleria [19] studied about the concentration (1.5-2\%) of neem oil as a surface coating along with pre-cooling at $10^{\circ} \mathrm{C}$ was the most effective in providing a better physico-chemical umbrella, significantly lowering the fruit spoilage. The neem oil surface coating along with shrink-wrapped tray packing at $2^{\circ} \mathrm{C}(85 \%$ to $90 \% \mathrm{RH})$ resulted in the longest storage life up to 150 days. Among the rates tested, the highest retention of fruit firmness, and pectin content, anthocyanin pigments, and polygalacturonase enzyme activity in fruits was recorded by $20 \%$ marigold extract, surface coated with shrink-wrapped tray packing along with pre-cooling. Arya [26] reported that higher concentration (75\%) leaf extract of neem was effective in reducing spores $(82.3 \%)$ of two fruit rot pathogens, Phomopsis psidii and Phomopsis viticola. From Table 1 the pre and post inoculation rot could not be checked completely by any plant extract but, the disease severity was reduced with all the plant extracts in comparison to control [27].

Chauhan and Joshi [22] reported the efficacy of phytoextracts on the storage quality of mango cv. Ratna and found them significantly better in retaining total soluble solids and sugar contents and in reducing reduction in the possible incidence of anthracnose pathogen in comparison to untreated fruits where lower soluble solid and sugar content and higher incidence of anthracnose pathogen was reported. The increase in TSS and sugar content may be due to the hydrolysis of insoluble polysaccharides into simple sugars. Such changes are expected to be slower and more gradual when the metabolism of

\begin{tabular}{|c|c|c|c|c|}
\hline \multirow{2}{*}{ Treatment } & \multicolumn{4}{|c|}{ Fruit Rot Severity (\%) } \\
\cline { 2 - 5 } & $\begin{array}{c}|c| \\
\text { Pre-Inoculation } \\
\text { Days after } \\
\text { inoculation (DAI) 3 }\end{array}$ & (DAI) 6 & Post-Inoculation \\
\hline Aloe Vera & 2.75 & 4.25 & 3.25 & 4.75 \\
\hline Jatropha & 0.00 & 2.75 & 0.00 & 3.00 \\
\hline Neem seed kernel & 3.25 & 5.75 & 3.50 & 6.00 \\
\hline Garlic & 0.00 & 2.35 & 0.00 & 2.50 \\
\hline
\end{tabular}

Table 1: Table showing the effect of per inoculation and post-inoculation treatments on severity of Aspergillus rot in Aonla fruits. 
the commodity is slowed down by the application of various coating treatments, pre-cooling and under low temperature storage.

Tiwari [28] Rao and Singh [29] have reported beneficial effect of various botanical extracts such as neem leaf extract, Melia leaf extract, onion extract, garlic extract, mahua extract and eucalyptus extract on the post-harvest quality of fruits and vegetables. They are also reported to act as antifeedent and antirepellent agents against various storage pathogens. Rameshwar et al. [24] observed that a combination of neem leaf extract at $20 \%+\mathrm{UV}$ radiation exposure for 10 minutes + rice starch $6 \%$ proved to be the most appropriate treatment in minimizing the reduction of juice contents and fruit rotting and fluctuation in physiological loss in weight was also minimum as compared to control.

Deshmukh et al. [21] have reported beneficial effects of Melia (Melia Azadirachta) and bavistin in controlling the storage fungi and insect-pests. They have also advocated commercial use of Melia extract as a substitute for fungicides and insecticides. Melia azedarach L. extracts were studied in comparison with selected biorational insecticides against the citrus leaf miner Phyllocnistis citrella Stainton under field conditions. Citrus limon (L.) Burm. F. trees were exposed to: Melia extracts of green and mature fruits, Neem oil (30\% a.i.), abamectin ( $1.8 \%$ a.i.) and control. Two sprays of each treatment (except for Melia mature fruit extract) were executed at 10-day intervals. The live number of the $1^{\text {st }}$ and later $\left(2^{\text {nd }} \& 3^{\text {rd }}\right)$ larval instars per leaf were recorded at initial sampling date and at 10-day intervals after each spray application. Results indicated that there were significant differences in the number of live larval instars among treatments. Melia extracts and the two biorationals, neem oil and abamectin, decreased the larvae population significantly to lower numbers than that of the control at 10 days after each spray application. However, the decrease caused by neem oil and abamectin was significantly higher than that of Melia extracts. Thus, these extracts might be considered as potential alternative with other biorational control methods in management of the leaf miner. Further research including bioassays is needed to determine the factors responsible for reducing larvae population and whether these Melia extracts can be utilized in future citrus IPM programs as a tool for citrus leaf miner management [30].

Lehmann and Ibenthal [31], Bottenburg and Singh [32] reported beneficial effects of treatments with neem leaf and mentha leaf extract on the marketing quality characteristics of cow pea and sugar beet and concluded that these treatments were effective in retaining the physicochemical characteristics of these crops. The TSS, acidity, phenols and ascorbic acid showed less decrease as compare to the control. In control the degradation of quality is more as compare to that of treated with neem leaf and menthe leaf extract. Sarvamangla [33] studied the effect of leaf extracts from Azadirachta indica, Calotropis gigantean, Calthranthus sp. Eucalyptus sp., Parthenium chysterophorus and Pongamia pinnata on fruit quality of mulberry and reported that among these extracts Azadirachta indica was the most effective in retaining higher sugar content, maintaining fruit size and shape, and resistance to fungal pathogens. Azadirachta indica control the fungal pathogen more effectively and retaining the maximum sugar content as compare to Calotropis gigantean, Calthranthus sp. Eucalyptus sp., Parthenium chysterophorus and Pongamia pinnata (Table 2).

Srivastava and Lal [34] reported that leaf extract of Azadirachta indica was effective in the control of fruit rot of pear and pomegranate. Sindhan et al. [35] reported the beneficial effects of neem, eucalyptus, tulsi, datura, bougainvillea and ginger on the bio-chemical and physical quality characteristics of citrus and mango fruits, as these extracts significantly reduced moisture loss and retained higher soluble solid content over the uncoated fruits. Rameshwar et al. [24] observed that a combination of neem leaf extract at $20 \%+$ UV radiation exposure for 10 minutes + rice starch $6 \%$ proved to be the most appropriate treatment in minimizing the reduction of juice contents and fruit rotting and fluctuation in physiological loss in weight was also minimum as compared to control (Table 2). Bhardwaj and Sen [36] observed that PLW, rotting, loss in juice content and reduction in diameter of fruits of sweet orange cv. Nagpur Santra under zero energy cool chamber $+20 \%$ neem leaf extract were significantly less, whereas high under ambient condition $+10 \%$ neem leaf extract after 42 days of storage. Borthakar et al. [37] conducted experiments on the effects of neem leaf $(5 \%)$, melia leaf (5\%) garlic (5\%) and neem oil (2\%) on physicochemical characteristics of Baramasi lemon fruit and concluded that among various treatments neem leaf extract and melia leaf extract was better in retaining most of the physico-chemical characteristics of fruits.

Chauhan et al. [38] treated apple cv. Starking Delicious with plant leaves/flower based formulation of neem leaf extract (10\%, 20\%), spearmint (Mentha spicata) leaf extract (10\% and $20 \%$ ), marigold (Tagetes erecta) flower extract $(10 \%, 20 \%)$ and semper fresh (control $1.5 \%)$. Freshly harvested fruits were treated with above treatments and were kept under refrigerated storage $\left(1 \pm 1^{\circ} \mathrm{C}\right)$ for analysis at a month interval up to 180 days. Among treatments, $20 \%$ spearmint leaf extract proved to be highly effective in reducing fruit spoilage followed by $20 \%$ neem leaf extract. Fruit treated with $20 \%$ drake leaf extract proved to be most effective treatment in reducing weight loss and also $20 \%$ drake and $20 \%$ neem leaf extract were capable to retain maximum total soluble solids. Similar findings have been reported by Ali et al. [39], Abid and Maqbool [40] on tomato fruits.

Bhardwaj and Sen [37] studied the effect of different concentrations of neem leaf extracts on the storage quality of mandarin (Citrus reticulata) cv. Nagpur Santra and reported that among various treatments used neem leaf extract (20\%) was significantly better in retaining higher ascorbic acid content $(27.17 \mathrm{mg} / 100 \mathrm{ml}$. of juice) as compared to control fruits where it was only after storage. Chaudhary [41] reported that aqueous extracts from different plants can be a viable alternative to chemicals in controlling post-harvest pathogens as they are environmentally safe strategies for controlling the post- harvest storage pathogens in different crops. Singh et al. [42] also reported the effect of various extracts such as neem leaf extract, castor oil and neem oil on citrus fruits and reported that, among these extracts neem was best in retaining most of biochemical characteristics such as TSS $\left(16.01^{\circ} \mathrm{B}\right)$, acidity $(0.38 \%)$, pectin $(0.98 \%)$ and ascorbic acid content

\begin{tabular}{|c|c|c|c|}
\hline Name & Plant species & Family name & Nature of the extract \\
\hline Neem & Azadirachta indica $L$. & Meliaceae & Leaf powder \\
\hline Hot chili & Capsicum frutescence $L$. & Solanaceae & Fruit powder \\
\hline Lemon grass & Cymbopogon nardus $L$. & Poaceae & Leaf powder \\
\hline Turmeric & Curcuma longa $L$. & Zingiberaceae & Anti-fungal \\
\hline Ginger & Zingiber officinale $L$. & Zingiberaceae & Anti-fungal \\
\hline
\end{tabular}

Table 2: Table showing the effect of per inoculation and post-inoculation treatments on severity of Aspergillus rot in Aonla fruits. 
(20.56 $\mathrm{mg} / 100 \mathrm{ml}$ juice) as compared to control fruits in which the values for these parameters were $12.03^{\circ} \mathrm{B}, 0.23 \%, 0.55 \%$ and 15.68 $\mathrm{mg} / 100 \mathrm{ml}$ juice, respectively after 12 days of storage.

Singh et al. [43] observed that the quality of untreated mango cv. Langra fruit started deteriorating after about two weeks of storage and the fruits became unacceptable after five weeks. However, the fruits were reported to be acceptable even after five weeks of storage when they were given post-harvest dip of $\mathrm{GA}_{3}(500 \mathrm{ppm})$ and $20 \%$ neem leaf extract and retained high pectin content $(0.98 \%)$ over the control $(0.55 \%)$ fruits. Singh et al. [42] tested the efficacy of aqueous leaf extracts of 20 plant species and 3 essential oils against management of Penicillium expansum rot of apple cv. Red Delicious. Among various treatments leaf extract of Azadirachta indica significantly reduced $P$. expansum rot when used as post-infection dip treatment. Chauhan et al. [38] treated apple cv. Starking Delicious with plant leaves/ flower based formulation of neem leaf extract (10\%, 20\%), spearmint (Mentha spicata) leaf extract $(10 \%, 20 \%)$, marigold (Tagetes erecta) flower extract $(10 \%, 20 \%)$ and semper fresh (control 1.5\%). Freshly harvested fruits were treated with above treatments and were kept under refrigerated storage $\left(1 \pm 1^{\circ} \mathrm{C}\right)$ for analysis at a month interval up to 180 days. Among treatments, $20 \%$ spearmint leaf extract proved to be highly effective in reducing fruit spoilage followed by $20 \%$ neem leaf extract. Fruit treated with $20 \%$ drake leaf extract proved to be most effective treatment in reducing weight loss and also $20 \%$ drake and $20 \%$ neem leaf extract were capable to retain maximum total soluble solids. Hassanein et al. [44] studied the effectiveness of leaf extracts of neem and china berry against two tomato pathogenic fungi Alternaria solani and Fusasuim oxysporum, the causal agent of early blight and wilt disease of tomato plants respectively and reported promising results. Jakhar et al. [45] reported that the physiological loss in weight, colour, texture, shriveling and rotting of Chakaiya cultivar of aonla fruit was significantly affected by packaging materials, neem leaf extracts and diphenyl fumigation and their combination throughout the storage period up to 21 days.

Patel et al. [46] reported that the extract from Allium sativum was significantly better followed by extract of Jatropha curcas, Aloe barbadensis and Azadirachta indica in controlling Aspergillus niger of aonla fruit rot. Okigbo et al. [47] used ethanolic and water extractions of Azadirachta indica leaves and Aframomum melegueta seeds as antifungal agents against pathogenic fungi Aspergillus niger, Botryodiplodia theobromae, Fusarium solani and Penicillium oxalicum of cassava and reported that $A$. indica was more active on the organisms than A. melegueta in preventing post-harvest deterioration of cassava. Bhardwaj et al. [48] reported that Azadiracta indica and Chromoleana odorata were able to suppress rot-causing fungi of yam. Therefore, serve as a good natural plant fungicide (protectant) against yam tubers in storage.

\section{Conclusion}

Plant extracts are being used to manufacture natural or bio insecticides, which are environmental friendly and do not have any toxic effects on plants and soil. More ever they possess fungicidal and insecticidal properties. So these can be used as compare to synthetic/ chemical products. Various extracts such as neem leaf extract castor oil and neem oil on citrus fruits and reported that, among these extracts neem was best in retaining most of biochemical characteristics such as TSS, acidity, pectin and ascorbic acid content. Moreover the extract of neem, marigold and other plant extracts increase the shelf life of the fruits and vegetables by reducing the fungal and bacterial spoilage during storage. Neem extracts was best in retaining most of biochemical characteristics such as TSS, acidity, pectin and ascorbic acid content. Plant extracts are important in order to reduce the environmental pollution by synthetic chemicals. In day to day life the world is facing the threat of global warming and pollution, in order to contribute in keeping the environment clean to some extent and reduce the residual effect of synthetic insecticide and pesticides.

\section{References}

1. Choulwar AB, Datar VV (1988) Cost linked spray scheduling for management of tomato early blight. Indian Phytopathol 41: 603-606.

2. Maheshwari SK, Gupta PC, Gandhi SK (1991) Evaluation of different fung toxicants against early blight of tomato. Agriculture Science Digest 11: 201-202

3. Abdul Mallek AY, Hemida SK, Bagy MK (1995) Studies on fungi associated with tomato fruits and effectiveness of some commercial fungicides agains three pathogens. Mycopathologia 130: 109-116.

4. Wijewardane RMNA, Guleria SPS (2009) Combined effect of Pre-cooling application of natural extracts and packaging on the storage quality of Apple (Malus domestica) cv. Royal Delicious. Tropical Agricultural Research 21: 1020.

5. Schmutterer H (1995) The Neem Tree. Publisher VCH verlagsgesells chaft weinheim (Federal Republic of Germany) and VCH Publishers Inc., New York, USA.

6. Fishwick RW (1989) Neem (Azadirachta indica A. Juss) Plantations in the Sudan Zone of Nigeria Rep. Prepared for the Chief Conservator of Forests, Northern Nigeria.

7. Eeswara JP, EJ Allan, AA Powell (1998) The influence of storage of seed maturity, moisture content and storage temperature on the survival of neem (Azadirachta indica) seed in storage. Seed Sci Technol 26: 299- 308.

8. Siddiqui BS, Afshan F, Gulzar T, Hanif M (2004) Tetracyclic triterpenoids from the leaves of Azadirachta indica. Phytochemistry 65: 2363-2367.

9. Hassanein NM, Abou Zeid MA, Youseef KA, Mahmoud DA (2008) Efficacy of neem (Azadirachta indica) and $\mathrm{C}$ hinaberry (Melia azedrach) against early blight and wilt of tomato. Aus J Basic Appl Sci 2: 763-772.

10. Ilondu EM, Ejechi BO, Souzey JA (2001) Microbial stability of jam prepared from velvet tamarind and preserved bycombined processes. Nig J Microbio 5: 93-96.

11. Ahmed S, Stoll G (1996) Biopesticides. In: Haverkort JB, Hiemstra W (eds.) Biotechnology: Building on Farmers' Knowledge. Macmillan Education Ltd, Bunders, London.

12. Bajwa AA, Ahmad A (2012) Potential applications of Neem based products as biopesticides. The Health 3: 116-120.

13. Butterworth JH, Morgan ED (1971) Investigation of the locust feeding inhibition of the seeds of the neem tree, Azadirachta indica. J Insect Physiol 17: 969-977.

14. Lavie D, Jain MK, Shpan-Gabrielith SR (1967) A locust phago-repellent from two media species. Chem Comm 13: 910-911.

15. Verkerk RHJ, Wright DJ (1993) Biological activity of neem seed kernel extracts and synthetic azadirachtin against larvae of Plutella xylostella L. Pestic Sci 37 83-91.

16. Akou-Edi D (1984) Effects of neem seed powder and oil on Tribolium confusum and Sitophilus zeamais. In: Schmutterer H, Ascher KRS (eds.) Natura pesticides from the neem tree (Azadirachta indica A. Juss) and other tropical plants. Rauischholzhausen, Federal Republic of Germany, pp: 445-452.

17. Schmutterer H (1990) Properties and potential of natural pesticides from the neem tree, Azadirachta indica. Annu Rev Entomol 35: 271-297.

18. Nawrot J, Harmatha $\mathrm{J}(1994)$ Natural products as antifeedants against stored products insects. Postharv News Inf 5: 17-21.

19. Wijewardane RMNA, Guleria SPS (2009) Combined Effects of Pre-cooling Application of Natural Extracts and Packaging on the Storage Quality of Apple (Malus domestica) cv. Royal Delicious 21: 10-20.

20. Florence V, Dunkel, David CR (2008) Effect of an Azadirachtin Formulation on Six Nontarget Aquatic Macroinvertebrates; Environ. Entomol 27: 667-674. 
Citation: Anjum Malik A, Ahmed N, Babita, Chauhan H, Gupta P (2016) Plant Extracts in Post-Harvest Disease Management of Fruits and Vegetables-A Review. J Food Process Technol 7: 592. doi:10.4172/2157-7110.1000592

Page 5 of 5

21. Deshmukh PB, Chavam SR, Rehapukar DM (1992) A study of insecticidal activity of twenty indigenous plants. Pesticide 16: 7-10.

22. Chauhan HI, Joshi HN (1990) Evaluation of phyto extracts for control of mango anthracnose. Proceedings of Symposium of Botanical Pesticides.

23. Pandey RS, Bhargava SN, Shukla DN, Dwivedi KK (1983) Control of pestololia fruit rot of guava by leaf extracts of two medicinal plants. Revists Mexic Fito 2: 15-16

24. Rameshwar, Dayal, Jeewa, Ram, Shafeal, et al. (1987) Role of Post-harvest treatment with plant extracts, ultra violet radiation and rice starch on keeping quality of Sweet Orange (Citrus sinesis osbeck) cv. mosambi. J Eco Physiol.

25. Hasabnis SN, D'Souza TF (1987) Use of natural products in the control of the storage rot in alphanso mango fruits. J Maharashtra Agri Univer 12: 105-106.

26. Arya A (1988) Control of phomosis fruit rot by leaf extract of certain medicinal plants. In: Kaushik P (eds.). Indigenous Medicinal Plants. Symposium. Today and Tomorrows Printers and Publishers, New Delhi, pp: 41-46.

27. Patel DS, Nath K, Patel RL, Patel SI (2008) Management of fruit rot of Aonla caused by Aspergillus niger. 38: 658-651.

28. Tiwari DN (1991) Monograph on neem (Azadirachta indica). International book distribution New Delhi, India.

29. Rao PJ, Singh S (1999) Effect of Artemisia vulgaris on the development of various pests during storage. Indian J Entomol 61: 305-314

30. Maher MM, Efat MA, Fakhr Hammad, Mohamad TF (2013) Effect of Melia zedarach (Sapindales: Meliaceae) fruit extracts on Citrus Leafmine Phyllocnistis citrella (Lepidoptera: Gracillariidae) 2: 144

31. Lehmann W. and Ibenthal WA. Fungicidal effects of neem extracts against seedling blight of sugar bet. Symposium on useful Tropical Plants, Hamburg, Germany.

32. Bottenburg BH, Singh BD (1996) Effect of neem leaf extract applied using the broom method on cow pea pests and yield. Int J Pest Manag 42: 207-209.

33. Sarvamangla HS (1993) Evaluation of plant extract for the control of funga disease of blackberry. Indian Phytopath 46: 398-401.

34. Srivastava AK, Lal P (1997) Studies on bio fungicidal properties of leaf extracts of some plant. Indian Phytopath 50: 408-411.

35. Sindhan GS, Hooda, Indira, Prashar RD (1999) Effect of some plant extracts on the vegetative growth and storage rot causing fungi. J Mycol Plant Pathol 29: $110-111$

36. Bhardwaj RL, Sen NL (2003) Physico-chemical changes of stored mandarin orange (Citrus reticulata Blanco) cv. 'Nagpur Santra' as affected by neem leaf extract and zero energy cool chamber. South Indian Horti 50: 500-504.

37. Borthakar PK, Ranjit K, Kumar R (2002) Effect of plant extract on size and rind thickness of Baramasi lemon fruit (Citrus lemon) during storage. J Agri Sci Soc North-East India 15: 98-103.

38. Chauhan, Sandeep K, Thakur KS, Bhanot, Amandeep, et al. (2008) Effect of pre and postharvest treatment of neem (Azadirachta indica) based formulations, plant leaves and their extracts on the storage quality of apple (Malus domestica). Indian J Agri Sci 78: 966-970.

39. Ali TE, Nasir MA, Shakir AS (1992) In-vitro evaluation of certain neem products as mould inhibitors against post-harvest rotting fungi of tomato. Pak J Phytopathol 4: 58-61.

40. Abid M, Maqbool MA (1991) Effect of bare-root dip treatment in oil cakes of neem leaf extract on the root-knot development and growth of tomato and eggplant. Pak J Nematol 9: 13-16.

41. Chaudhary M (2003) Studies on the post-harvest diseases of tomato and their management. Dr. Y.S. Parmar University of Horticulture and Forestry, NauniSolan (HP).

42. Singh, Dinesh, Thakur RK, Singh D (2003) Effect of pre harvest sprays of fungicides and calcium nitrate on post-harvest rot of kinnow in low temperature storage. Plant Dis Res 18: 9-11.

43. Singh JN, Acharya P, Singh BB (2000) Effect of GA3 and plant extracts on storage behavior of mango (Mangifera indica) cv Langra. Har J Horti Sci 29: 3-4.

44. Hassanein MM, Abou Zeid MA, Youssef KA, Mahmoud DA (2008) Efficacy of leaf extracts of neem (Azadirachta indica) and chinaberry (Melia azedrach) against early blight and wilt disease of tomato. Aus J Basic Appl Sci 2: 763-772.

45. Jakhar RP, Dheeraj Singh (2008) Post-harvest effect of packaging material neem leaf extract and fumigation on color, texture, shriveling and rotting of aonla (Emblica officinalis). Environ Eco 26: 1652-1656.

46. Patel DS, Nath K, Patel RL and Patel SI. Management of fruit rot of aonla caused by Aspergillus niger. J Mycology Plant Pathol 38: 658-660.

47. Okigbo RN, Putheti, Ramesh, Achusi CT (2009) Post-harvest deterioration of cassava and its control using extracts of Azadirachta indica and Aframomum melegucta. E-Journal Chem 6: 1274-1280.

48. Bhardwaj RL, Dhashora LK, Mukherjee S (2010) Effect of plant extract and benzyladenine on post-harvest shelf life of orange (Citrus reticulata Blanco). J Adv Dev Res 1: 32-37. 